УДК 781.68:786.2
DOI https://doi.org/10.31723/2524-0447-2020-30-2-32

Уляна Богданівна Молчко

ORCID: 0000-0003-1519-6053

доцент кафедри музикознавства та фортепіано

Навчально-наукового інституту музичного мистецтва

Дрогобицького держсавного педагогічного університету

імені Івана Франка

u.molchko@gmail.com

\title{
ЩОДО ПРОБЛЕМ ІНТЕРПРЕТАЦІЇ «ЧАБАРАШОК» ДЛЯ ФОРТЕПІАННОГО ДУЕТУ СТАНІСЛАВА ЛЮДКЕВИЧА
}

Мета роботи - здійснити музично-естетичний аналіз ансамблевих n'єс С. Людкевича й обгрунтувати комплекс виконавських засобів виразності для втілення образно-емоційної сфери. Методологія дослідження спирається на системно-аналітичний $і$ компаративний методи. Наукова новизна полягає в здійсненні виконавського аналізу «Чабарашок» С. Людкевича з погляду інтерпретаційних проблем, які зумовлені жанрово-стилістичними особливостями, фактурним викладом ансамблевих творів, художньо-образним наповненням. Також здійснюється спроба привернути увагу піаністів до маловідомих композицій корифея української музики задля уведення їх до концертних і навчальних програм. Висновки. Інструментальні ансамблеві твори українських композиторів становлять невід 'ємну частку концертного та педагогічного репертуару сучасних піаністів. Фортепіанні п'єси фундатора національної музики Станіслава Людкевича є скарбницею української музики, глибоке художньо-образне наповнення й жанрово-стилістичне різноманіття ставить їх у рівень мистецьких надбань світової культури. Ансамблеві композиції для фортепіано львівського мития становлять неповторну сторінку української камерно-інструментальної музики. Розуміючи нестачу національного педагогічного репертуару для молоді, С. Людкевич у 1912-1913 роках створює декілька чабарашок для дуету піаністів. «Чабарашки» для фортепіано в чотири руки трунтуються на жанрових ознаках маловідомого зразка українського народного танцю. Танець чабарашка є одним із маловідомих взіриів народної інструментальної музики й досить рідко застосовувався митиями в професійній композиторській творчості. Ритмічне розмаїття, синкоповані послідовності, застосування ладів народної музики споріднюють ці ансамблеві п'єси $з$ карпатськими фольклорними зразками коломийок. Аналізуючи багату

(C) Молчко У. Б., 2020 
фактуру обох партій, у яких застосовано оркестрові прийоми викладу музичного матеріалу, автор статті наголошує на романтичних стильових ознаках п'єс. Дослідження підтверджує мистецьку й дидактичну вартість «Чабарашок» для фортепіано в чотири руки, котрі варто впроваджувати в концертний $і$ навчальний процес.

Ключові слова: С. Людкевич, чабарашки, фортепіанний ансамбль, виконавська інтерпретація, українська народна танцювальна музика, інструментальна фактура.

Molchko Uliana Bohdanivna, Associated Professor at the Science Musical Sociography and Pianoforte Department of the Education and Researcher Musical Art Institute of Drohobych Ivan Franko State Pedagogical University

To the problems of interpretation of Stanislav Lyudkevych's "Chabarashky" for piano duet

Objective of the work - conduct musical-aesthetic analysis of S. Lyudkevych's ensemble plays and to substantiate a complex of performing expression means for the embodiment of figurative-emotional sphere. The methodology is based on system-analytical and comparative methods. The scientific novelty lies in the performance analysis of $S$. Lyudkevych's "Chabarashky" from the point of view of interpretive problems, which are determined by genre and stylistic peculiarities, ensemble works textural presentation, artistic and figurative content. There is also an attempt to draw the pianists' attention to the little-known compositions of the Ukrainian music leading figure in order to introduce them to concert and educational programs. Conclusions. Instrumental ensemble works of Ukrainian composers are an integral part of the concert and pedagogical repertoire of modern pianists. The piano pieces of the national music founder Stanislav Lyudkevych are a treasure house of Ukrainian music, the deep artistic and figurative content, genre and stylistic diversity put them at the level of world culture artistic heritage. Ensemble compositions for piano by the Lviv artist constitute a unique page of the Ukrainian chamber and instrumental music. Realizing the lack of national pedagogical repertoire for young people, S. Lyudkevych in 1912-1913 created several chabarashkas for a piano duet. "Chabarashky" for the four hands piano playing is based on the genre features of a littleknown example of Ukrainian folk dance. Chabarashka's dance is one of the little-known examples of folk instrumental music and has been rarely used by artists in professional composition. Rhythmic diversity, syncopated sequences, application of folk music modes make these ensemble pieces related to Carpathian folklore samples of kolomyiky. Analyzing the rich texture of both parts, in which the orchestral methods of presenting the musical material are used, the author of the article emphasizes the romantic stylistic features of the plays. The research confirms the artistic and didactic value of "Chabarashky" for the four hands piano playing, which should be introduced into the concert and educational process.

Key words: S. Lyudkevych, chabarashky, piano ensemble, performance interpretation, Ukrainian folk dance music, instrumental texture. 
Молчко Ульяна Богдановна, доцент кафедры музыковедения и фортепиано Учебно-научного института музыкального искусства Дрогобычского государственного педагогического университета имени Ивана Франко

К проблемам интерпретации «Чабарашок» для фортепианного дуэта Станислава Людкевича

Цель работы - осуществить музыкально-эстетический анализ ансамблевых пьес С. Людкевича и обосновать комплекс исполнительских средств выразительности для воплощения образно-эмоциональной сферы. Методология исследования опирается на системно-аналитический и компаративный методы. Научная новизна заключается в осуществлении исполнительного анализа «Чабарашок» С. Людкевича с точки зрения интерпретационных проблем, обусловленных жсанрово-стилистическими особенностями, фактурным изложением ансамблевых произведений, художественно-образным наполнением. Также осуществляется попытка привлечь внимание пианистов к малоизвестным композициям корифея украинской музыки для введения их в кониертные и учебные программы. Выводы. Инструментальные ансамблевые произведения украинских композиторов составляют неотъемлемую часть концертного и педагогического репертуара современных пианистов. Фортепианные пьесы основателя национальной музыки Станислава Людкевича являются сокровищницей украинской музыки, глубокое художественно-образное наполнение и жанрово-стилистическое многообразие ставит их в уровень художественных достижений мировой культуры. Ансамблевые композиции для фортепиано львовского музыканта составляют неповторимую странииу украинской камерно-инструментальной музыки. Понимая недостаток национального педагогического репертуара для молодежи, С. Людкевич в 1912-1913 годах создает несколько чабарашок для дуэта пианистов. «Чабарашки» для фортепиано в четыре руки основываются на жанровых признаках малоизвестного образиа украинского народного танца. Танец чабарашка является одним из малоизвестных образиов народной инструментальной музыки и достаточно редко применялся художниками в профессиональном композиторском творчества. Ритмичное разнообразие, синкопированные последовательности, применение ладов народной музыки роднят эти ансамблевые пьесы с карпатским фольклорным образцом коломыйки. Анализируя богатую фактуру обеих партий, в которых применены оркестровые приемы изложения музыкального материала, автор статьи отмечает романтические стилевые признаки пьес. Исследование подтверждает художественную и дидактическую ценность «Чабарашок» для фортепиано в четыре руки, которые стоит внедрять в концертный и учебный процесс.

Ключевые слова: С. Людкевич, чабарашки, фортепианный ансамбль, исполнительская интерпретация, украинская народная таниевальная музыка, инструментальная фактура. 
Актуальність теми дослідження. Фортепіанні твори для ансамблевого виконання у кінці XIX початку XX століття в Східній Галичині набули широкого застосування в домашньому середовищі. Українські митці західного регіону, такі як Ярослав Лопатинський, Денис Січинський, Ярослав Ярославенко, Борис Кудрик, Василь Витвицький, Василь Безкоровайний, Марта Кравців-Барабаш, створили чимало дуетних композицій для піаністів. У фортепіанному доробку фундатора української музики Станіслава Людкевича є низка фортепіанних п'єс для виконання в чотири руки. Це військовий марш «Під мурами Ерихону» з опери "Bar Kochba", січовий марш «Ой ішли наші славні запорожці», «Швачка-марш», «Меланхолійний вальс». У 2014 році вони побачили світ у нотному виданні «Станіслав Людкевич. П'єси для двох фортепіано та для фортепіано в чотири руки». «Чабарашки», які створені на початку XX століття, не ввійшли до цього сучасного збірника й залишилися поза увагою музичної громадськості. Тому розгляд цих композицій для фортепіанного ансамблю є актуальним сьогодні, що дасть змогу ввести їх до наукового обігу, а аналіз інтерпретаційних проблем уможливить широке застосування їх у виконавській практиці.

Про наявність ансамблевих фортепіанних п'єс лаконічно згадано в працях про С. Людкевича авторами А. Кос-Анатольським [6], М. Загайкевич [4], С. Павлишин [10], Г. Брилинською-Блажкевич [1]. Уперше вони зазначені в повному обсязі в нотографічному переліку музичних композицій митця, опублікованому в першому томі монографії Зеновiї Штундер [11, с. 605]. Проблеми інтерпретації окремих творів для фортепіанного дуету львівського митця висвітлювали О. Німилович [9] і Т. Воробкевич [7]. У зазначених вище виданнях ми не знаходимо музикознавчого аналізу та виконавських характеристик «Чабарашок» для фортепіано в чотири руки С. Людкевича.

Мета дослідження - здійснити музично-естетичний аналіз ансамблевих п’єс С. Людкевича й обгрунтувати комплекс інтерпретаційних засобів виразності для втілення образно-емоційної сфери.

Наукова новизна полягає в здійсненні виконавського аналізу «Чабарашок» для фортепіанного дуету С. Людкевича 3 погляду інтерпретаційних проблем, які зумовлені жанрово-стилістичними особливостями, фактурним викладом 
ансамблевих творів, художньо-образним наповненням, а також приверненні уваги піаністів до маловідомих композицій корифея української музики задля уведення їх до концертних і навчальних програм.

Виклад основного матеріалу. Процес творчого становлення композиторської індивідуальності С. Людкевича тісно пов'язаний із його глибоким інтересом і постійним зверненням до фольклорних першоджерел. Вихід у світ у 1906-1907 роках двох томів редагованої ним збірки «Галицько-руські народні мелодії» розкрив багатство західноукраїнського мелосу. Митець весь час відстоював «ідею популяризації кращих зразків пісенності» [8, с. 120] і народної танцювальної музики, а також надавав значну увагу їх уведенню у свої твори та музичний побут. Так, серед численних інструментальних п'єс, що опираються на фольклорні традиції, вирізняються «Чабарашки» для фортепіано в чотири руки.

Віктор Клин у праці «Українська радянська фортепіанна музика» відзначає, що народні танці, зокрема веснянка, коломийка, козачок, шумка, чабарашка, стали добрим «художнім фольклорно-тематичним і конструктивно-формотворчим джерелом жанру танцю в українській фортепіанній музиці» [5, с. 23]. Танець чабарашка є одним із маловідомих узірців народної інструментальної музики та досить рідко застосовувався митцями в професійній композиторській творчості. Найчастіше звертався до цього жанру М. Завадський (1827-1887). Ним створено «Чабарашки 3 Поділля, Волині, України» тв. 322; «Три українські чабарашки» тв. 324; «Українські танці. Чабарашки. П'ять серій» тв. 339 [2, с. $133-134]$.

3 відомої збірки «Коломийки і шумки» Щасного Саламона (1863 р.) довідуємося про походження танцю чабарашка. Великою заслугою відомого фольклориста було те, як зазначає М. Загайкевич, що «він зумів показати жанрову різноманітність коломийкових наспівів та особливості їх виконання» [3, с. 61]. Дуже часто в коломийках на той самий мотив співають різні тексти, тому у виконавській практиці коломийкова мелодія певного типу охоплює визначений комплекс поетичних образів і текстів, близьких за змістом і настроями.

Відзначаючи цю особливість побутування коломийок, Щасний Саламон указує в примітках до своєї збірки, що «на першу мелодію виконуються переважно парубоцькі й 
вояцькі пісні, на другу - любовні, на третю - сирітські, на четверту - жартівливі (що їх називають також чабарашками) і на П’яту - шумки» [3, с. 61]. Працюючи над редагуванням «Галицько-руських народних мелодій», С. Людкевич у другому томі в окремому розділі під назвою «Інші відміни коломийок («шумки», «дрібушки», «чабарашки», «козачки», «тропаки» тощо)» [11, с. 528] також зазначає про належність цього танцю до коломийки. Дослідники життя і творчості С. Людкевича: А. Кос-Анатольський [6, с. 25], М. Загайкевич [4, с. 77], С. Павлишин [10, с. 29] - та автор монографії 3. Штундер [11, с. 528] підтверджують думку, що чабарашка $є$ різновидом коломийки.

Прагнучи широкого впровадження в національне мистецтво маловідомих зразків фольклору, С. Людкевич звертається до вже згаданого українського народного танцю, який своїм корінням сягає в давнє минуле. 3. Штундер у монографії пише, що «першим твором Людкевича для скрипки із супроводом фортепіано була знаменита «Чабарашка», створена в 1910 році. Після неї композитор написав ще кілька чабарашок для фортепіано в чотири руки як шкільний навчальний репертуар і цикл чабарашок на мішаний хор з супроводом симфонічного оркестру» [11, с. 547]. Таке розмаїття застосування цього танцю в різних ділянках композиторської творчості свідчить про особливу цікавість до нього.

Будучи директором Вищого музичного інституту ім. М. Лисенка у Львові, С. Людкевич стикається з браком національного педагогічного репертуару, тому продовжує творити п’єси для молоді. У 1912-1913 роках він пише декілька чабарашок для фортепіано в чотири руки.

«Чабарашка» d-moll (1912 рік) - це фортепіанна композиція на зразок вінка жартівливих пісень і танцювальних мелодій. Такого типу твори були досить поширені в українській музиці на зламі XIX і XX століть. Цикл чабарашок складається з восьми частин.

Тематичний матеріал першої частини зосереджений у партії Primo і складається з трьох мелодій у тональності $d$-moll. Розпочинається твір лаконічним чотиритактовим реченням, котре вводить слухача в піднесений настрій. Бадьорі співзвуччя на $f f$ і короткі унісонні поспівки, що викладені різноманітними ритмічними малюнками та прикрашені форшлагами, звучать на тлі пульсуючого супроводу партії Secondo. Наступна мело- 
дія відтінена динамікою $p$, авторською ремаркою leggiero. Її одноголосний виклад надає першій частині прозорого звучання, а високий регістр темброво споріднює тему із сопілковими награваннями. Така фактурна зміна вносить контраст у музичний розвиток. Рухаючись звуками мелодичного мінору та збагачена поєднанням різноманітних малюнків, які підкреслені дрібними штрихами, ця мелодична канва захоплює танцювальною динамічністю. Завершує частину тематичний матеріал початкового речення.

Тональність $D$-dur надає другій частині світлого, безтурботного відтінку. Музичний розвиток здійснюється за рахунок поєднання одноголосного й унісонного проведень теми. Композитор такими фактурними контрастами насичує частину оркестровими рисами. Друге проведення основної мелодії автор подає інтонаційно вище, а двоголосне повторення відтінене С. Людкевичем уведенням лідійського ладу. Оригінально та свіжо звучить третя поспівка, яку митець подає в тональності $B$-dur. Унісонний виклад танцювальної мелодії зв'язує одноголосні теми. Завершує другу частину дворазове проведення початкового речення зі вступу п'єси, котре є лейттемою в'язанки. Для супроводу властиві характерні ознаки, що притаманні народному інструментальному ансамблю. Це використання остинатних тонічних і домінантових звуків, на тлі яких з'являються хроматично збагачені послідовності подвійних терцій і секст. Уведення їх на слабих долях вносить у фактуру синкоповану ритміку, котра надає музичному матеріалу коломийкових ознак.

Розвиток тематичного матеріалу третьої частини автор здійснює за допомогою орнаментальної варіаційності. Мелодія наділена внутрішньою енергією за рахунок проведень іiі спочатку в гармонічному $a$-moll, а пізніше в гармонічному $d$-moll. Композитор застосовує контрастні виразові засоби для передачі запальної чабарашки. Це гострі акценти в обох партіях, короткі ліги, що підкреслюють танцювальну ритміку, а в інших місцях характерні одноголосні проведення на тлі легатного терцового супроводу. Оркестрові тремоло, що з'являються в третій частині, свідчать про застосування автором елементів симфонічного письма. Завершується розділ лейттемою, яка звучить спочатку в fis-moll, а пізніше $d$-moll.

Лаконічна четверта частина в тональності $a$-moll вирізняється від попередніх ритмічною одноманітністю. Музичний 
матеріал викладений митцем восьмими тривалостями. Карпатський колорит досягається С. Людкевичем уведенням гуцульського ладу.

Унісонна тема проводиться спочатку в партії Primo, а 3 наступного речення переноситься в партію Secondo. Ïї октавний виклад і гостре акцентування кожного звуку мелодії підкреслюють гумористичний характер п’єси. Жартівливість у цій частині в'язанки митець досягає контрастною динамікою.

Перехід до п’ятої частини С. Людкевич здійснює за допомогою лаконічного акордового вступу в тональності $a$-moll. Автор не застосовує тут зв'язуючої ролі лейттеми циклу. Композитор переносить ведення основної мелодії в партію Secondo. Низький тембр, синкопована ритміка, короткі ліги надають комічному образу п'єси нарочито примхливого відтінку. На зміну їй у партії Primo з'являється граціозна танцювальна тема на $p$.

Завдяки застосуванню в супроводі залігованих альтерованих звуків музична тканина насичується елементами поліфонічного письма. Наступне почергове проведення цих двох тем у різних фортепіанних партіях Людкевич збагачує комплексом віртуозних послідовностей і пасажами ламаних октав, токатним рухом, каскадом форшлагів, що прикрашають мелодичну канву. Завершує п'яту частину мажорно-мінорне звучання лейттеми циклу.

Танцювальна мелодія шостої частини підсилює грайливий характер в'язанки. Іскристу енергію в темі передають низхідна квартова інтонація, стрімкий рух вісімок угору на staccato звуками $A$-dur із підвищеним IV ступенем, терцові стрибки. Улюбленим технічним засобом є застосування мартелатної техніки, яка відтворює тут незгасаючий динамізм чабарашки. Супровід (партія Secondo) Людкевич насичує альтерованими тремоло та октавними ходами, що дають нам підставу стверджувати про оркестрове трактування митцем фортепіано.

Тематичний матеріал сьомої частини в $a$-moll розгортається 3 короткої поспівки на $p p$. Автор зазначає ремаркою misterioso iii характер. Із цього лаконічного мотиву виростає наступний музичний матеріал, який будується на секвенційному розвитку. Акомпануючі секундові інтонації «зітхання» в обох партіях надають початку частини жалібного відтінку. Прихід тональності $d$-moll і введення композитором акордово-октавної фактури змінюють їх настрій на рішучо-піднесений. 
Наступна тема на $p$ складається 3 коротких мотивів із трьох звуків, котрі досягають кульмінаційної точки висхідним рухом і збігають гамоподібним пасажем униз. Цей музичний матеріал отримує гуцульський колорит за рахунок альтерованих IV та VI ступенів. Модуляція в тональність $g$-moll, що забарвлена думним ладом, підводить тематичний розвиток до місця найвищого емоційного напруження, яке будується на швидко біжучих пасажах. За допомогою такого інструментального викладу автор відображає життєрадісно-танцювальний настрій частини. Низхідні гами втрачають свою напористість за рахунок їх мотивного скорочення й почергового звучання між партіями.

Восьма частина є тематичним повторенням початку твору, яку можна трактувати як репризу композиції. Октавно-акордовий супровід із багатою альтерацією сприяє завершенню циклу у святково-піднесеному настрої.

Кода побудована на лейттемі п’єси, котра подається Людкевичем у тональності $D$-dur. Ïї друге проведення багате на альтеровані ходи, які надають заключному розділу яскраво-карпатського колориту. У тринадцятому такті автор у партії Secondo проводить мелодію з четвертої частини. Але вона, проходячи на хвилі кульмінаційного підйому, звучить монументально підкреслено. Цьому сприяє темброве забарвлення низьким регістром, унісонний виклад, «клекочучи» оркестрове тремоло в партії Primo, що будується на співзвуччях, в основі яких лежить нижній трихорд $g$-moll із високим IV ступенем. Вир танцювальних емоцій доводиться композитором до піку завдяки багаторазовим повторенням чотиризвучних мотивів з уже згаданою альтерацією, які підводять до утвердження радісного $D$-dur.

«Чабарашка» D-dur (1913 рік) є транскрипцією для фортепіано в чотири руки популярної скрипкової мініатюри С. Людкевича. П'єса написана в простій тричастинній формі. Початкові співзвуччя в тональності $D$-dur, що з'являються на сильних долях тактів в обох інструментальних партіях, відразу настроюють слухача на вируючу енергію народного танцю. Головну тему п'єси, котра звучить у розмірі 2/4, проводить партія Primo. Веселого, жартівливого тону надає їй велика кількість форшлагів і мордентів, які наближують мелодію до взірців народної інструментальної музики. 
Подальший розвиток теми здійснюється композитором за допомогою «орнаментальної варіаційності» [4, с. 144]. Акомпанемент (партія Secondo), відображаючи експресію коломийки, нестримно пульсує в темпі Presto giocoso в токатному викладі. Постійні основні упори на тоніці та домінантовому звуці асоціюються з підігріванням басолі в ансамблі троїстих музик. Забарвлення лідійський ладом, що застосовано автором, надає цьому розділу гуцульського колориту. Гостре напруження в тематичний матеріал уносить рясність альтерацій.

Мелодія п’єси звучить як одноголосно, так і в унісон. С. Людкевич завершує іiі кожне проведення каскадом ламаних октав. Таке фактурне урізноманітнення споріднює інструментальний виклад 3 імпровізаційною виконавською манерою народних музикантів. Динамічна контрастність, яка детально виписана митцем у нотному тексті, передає загострену експресію танцювальних мелодій.

Середня частина твору Grave e mesto вносить різку зміну в настрій п’єси. Сумовита тональність d-moll i розмір s надають темі тужливого відтінку.

Ця лірична мелодія, що звучить у партії Primo, будується на інтонаціях основної теми з першої частини мініатюри, але набуває тут іншого характеру. Згладження ритмічного малюнку, сповільнення темпу та зміна ладу з мажорного на мінорний надають їй ознак протяжної пісні. Акомпанемент (партія Secondo), що насичений хроматично нестійкими ходами, підсилює в темі глибину драматичного висловлювання. Кінцеве одноголосне проведення мелодії композитор пропонує виконувати на $p p$ і morendo.

Третя частина п'єси, яка є точним повторенням першої, різко повертає слухача в стан танцювальної стихії. Завершує твір лаконічна шеститактова кода. Ця композиція С. Людкевича є талановитою творчою стилізацією під гуцульський танець, що безпосередньо виросла на народній музиці.

Висновки. Дві «Чабарашки» для фортепіано в чотири руки належать до високомистецьких національних композицій, які збагатили українську інструментальну ансамблеву музику. Вони глибоко опираються на народні джерела і проявляються у використанні фольклорних виразових засобів (ладово-гармонічного розмаїття, методів музичного розвитку, імітації ансамблю троїстих музик). С. Людкевич застосовує 
багатопланову романтичну фактуру, яка насичена оркестровими елементами. Інструментальний виклад $є$ піаністично-віртуозним, виконання котрого вдосконалить технічний рівень молодих музикантів. Сьогодні «Чабарашки» для фортепіано в чотири руки знаходяться в рукописному вигляді. Ці ансамблеві п’єси є добрим дидактичним матеріалом, котрий заслуговує на видання задля широкої популяризації й упровадження їх у навчальний процес і концертні програми сучасних виконавців.

\section{СПИСОК ЛІТЕРАТУРИ}

1. Брилинська-Блажкевич Г. Фортепіанна музика С. Людкевича. Львів, 1999. 125 с.

2. Дремлюга М. Українська фортепіанна музика (дожовтневий період). Київ : Державне вид-во образотворчого мистецтва і муз. літератури УРСР, 1958. 168 с.

3. Загайкевич М. Музичне життя Західної України другої половини XIX ст. Київ : Видавництво Академії наук Української РСР, 1960. $190 \mathrm{c}$.

4. Загайкевич М. Людкевич. Нарис про життя і творчість. Київ : Державне видавництво образотворчого мистецтва і музичної літератури, 1957. 154 с.

5. Клин В. Українська радянська фортепіанна музика (1917-1977). Київ : Наукова думка, 1979. 315 с.

6. Кос-Анатольський А. П. Людкевич. Київ : Мистецтво, 1951. 45 с.

7. Людкевич С. П'єси для двох фортепіано та для фортепіано в чотири руки / упорядкування, редакція та передмова Т. Воробкевич. Львів, 2014. 93 с.

8. Мурзіна О. Напрямки відбору і трансформації фольклорного матеріалу в обробках народних пісень С. Людкевича. Творчість C. Людкевича : збірник статей / упорядкування М. Загайкевич. Київ : Музична Україна, 1979. С. 117-145.

9. Німилович О. Твори для фортепіанного дуету Станіслава Людкевича. Станіслав Людкевич та Микола Колесса - корифеї українськоі музики XX століття / упорядник М. Ластовецький. Дрогобич : Коло, 2006. C. $14-18$.

10. Павлишин С. Станіслав Людкевич. Київ : Мистецтво, 1974. 50 с.

11. Штундер 3. Станіслав Людкевич. Життя і творчість. Том I (1839-1939). Львів : ПП «БІНАР-2000», 2005. 636 с.

\section{REFERENCES}

1. Brylynska-Blazhkevych, G. (1999). Piano music by S. Lyudkevych. Lviv [in Ukrainian].

2. Dremlyuga, M. (1958). Ukrainian piano music (pre-october period). Kiev: State Publishing House of Fine Arts and Music Literature of the USSR [in Ukrainian]. 
3. Zagaykevych, M. (1960). Musical life of Western Ukraine in the second half of the XIX century. Kiev: Publishing House of the Academy of Sciences of the Ukrainian [in Ukrainian].

4. Zagaykevich, M. (1957). S. Lyudkevich. Essay on life and work. Kiev: State Publishing House of Fine Arts and Music Literature [in Ukrainian].

5. Klin, V. (1979). Ukrainian Soviet piano music (1917-1977). Kiev: Naukova dumka [in Ukrainian].

6. Kos-Anatolsky, A. (1951). S. Lyudkevych. Kiev: Art [in Ukrainian].

7. Lyudkevych, S. (2014). Pieces for two pianos and for piano four hands / Arrangement, editing and preface by T. Vorobkevych. Lviv [in Ukrainian].

8. Murzina, O. (1979). Directions of selection and transformation of folklore material in arrangements of folk songs by S. Lyudkevych. Creativity of S. Lyudkevych. Collection of articles / Arranged by M. Zagaykevych. Kiev: Musical Ukraine. pp. 117-145 [in Ukrainian].

9. Nimilovich, O. (2006). Works for piano duet by Stanislav Lyudkevych. Stanislav Lyudkevych and Mykola Kolessa - luminaries of Ukrainian music of the XX century / Compiler M. Lastovetsky. Drogobich: Kolo. pp. 14-18 [in Ukrainian].

10. Pavlyshyn, S. (1974). Stanislav Lyudkevych. Kiev: Art [in Ukrainian].

11. Shtunder, Z. (2005). Stanislav Lyudkevych. Life and work. Vol. I (1839-1939). Lviv: PE "BINAR-2000" [in Ukrainian]. 